\title{
Interactions of Insulin, Insulinlike Growth Factor II, and Platelet-derived Growth Factor in Erythropoietic Culture
}

\author{
Nicholas Dainiak and Sandra Kreczko \\ Departments of Medicine and Biomedical Research, Division of Hematology/Oncology, St. Elizabeth's Hospital of Boston, and \\ Department of Medicine, Tufts University School of Medicine, Boston, Massachusetts 02135
}

\begin{abstract}
To examine the influence of insulin and insulinlike growth factor (IGF) on erythropoiesis, we tested their effects in human bone marrow cultures prepared with biochemically defined medium or a platelet-poor plasma-derived serum (PDS) that was depleted of hormones by adsorption to activated charcoal. Erythroid colony formation was enhanced two- to threefold by $10 \mathrm{ng} / \mathrm{ml}$ of electrophoretically pure IGF-II and $100 \mathrm{ng} / \mathrm{ml}$ of highly purified insulin $(P<0.05)$. Dose-response curves for IGF-II were parallel to and shifted by one to two orders of magnitude to the left relative to those for insulin. When added together to culture, IGF-II and insulin expressed additive activities. In contrast, their activities were synergistic with those of erythropoietin and burstpromoting activity. The erythropoietic actions of IGF-II and insulin were similar in PDS and whole blood serum (WBS) containing cultures. Furthermore, when added to cultures with electrophoretically pure platelet-derived growth factor, their respective activities were synergistic. We conclude that insulin and IGF-II potentiate human marrow erythropoiesis in vitro. Their activities appear to be mediated by a similar receptor or postreceptor system.
\end{abstract}

\section{Introduction}

Mammalian cell proliferation in tissue culture is regulated by serum mitogens that include hormones and hormonelike growth factors (1-3). Since human and murine erythropoiesis in vitro is supported by serum, it is likely that such growth-promoting molecules alter the proliferation of erythroid progenitor cells. Accordingly, many hormones have been shown to augment erythroid colony formation in culture (4-6). One such hormone, insulin, is a polypeptide that stimulates DNA synthesis and mitosis by cross-reactivity with receptors for structurally related peptides (insulinlike growth factors [IGFs] $]^{1}$ ) (7-9). Recently, we

A preliminary report of this research was presented at the 25th Annual Meeting of the American Society of Hematology, San Francisco, CA, and published in abstract form in 1983. Blood. 62:121.

Address reprint requests to Dr. Dainiak, Department of Biomedical Research, St. Elizabeth's Hospital, 736 Cambridge St., Boston, MA 02135. 1985.

Received for publication 4 January 1985 and in revised form 15 May

1. Abbreviations used in this paper: BFU-E, burst-forming unit, erythroid; BPA, burst-promoting activity; CFU-E, colony-forming unit, erythroid; CM, conditioned medium; IGF, insulinlike growth factor; IMDM, Iscove's modified Dulbecco's medium; PDGF, platelet-derived growth factor; PDS, platelet-poor plasma-derived serum; WBS, whole blood serum.

J. Clin. Invest.

(c) The American Society for Clinical Investigation, Inc.

0021-9738/85/09/1237/06 \$1.00

Volume 76, September 1985, 1237-1242 showed that the secretory protein platelet-derived growth factor (PDGF) is also a serum determinant of optimal human bone marrow colony-forming unit-erythroid (CFU-E) and burstforming unit-erythroid (BFU-E) proliferation (10). Mitogenic activity of this protein may explain differences in erythroid colony formation in cultures prepared with platelet-poor plasmaderived serum (PDS) and those containing whole blood serum (WBS).

To determine whether IGF alters erythropoiesis in vitro and to examine the relationships of potential erythropoietic action of IGF, insulin, and PDGF to that of erythropoietin and erythroid burst-promoting activity (BPA), we have measured the effect of each of these products alone and in combination on proliferation of CFU-E and BFU-E progenitors derived from human bone marrow. We have found that in cultures containing charcoal-adsorbed PDS or biochemically defined serum substitute, colony growth is significantly enhanced not only by insulin but also by IGF-II in a saturable fashion. The dose-response curve for IGF-II is parallel to and shifted leftward relative to that for insulin. While the activities of insulin and IGF-II are additive at a suboptimal concentration, they are independent of those expressed by PDGF, erythropoietin, and BPA in leukocyteconditioned medium. The data suggest that an IGF receptor system or postreceptor modification may mediate insulin stimulation of erythroid proliferation in vitro.

\section{Methods}

Preparation of growth factor and serum additives. WBS and PDS were prepared as described previously (10) according to the method of Vogel and co-workers $(11,12)$. Normal AB-positive volunteers were phlebotomized with informed consent and approval of an Institutional Review Board. Fresh blood mixed with 3.8\% sodium citrate was separated into two aliquots. It was either clotted immediately with $1 \mathrm{M} \mathrm{CaCl}_{2}$ (for WBS collection) or centrifuged twice at $1,100 \mathrm{~g}$ for $20 \mathrm{~min}$ at $4^{\circ} \mathrm{C}$ and 31,000 $g$ for $20 \mathrm{~min}$ to remove cells and platelets before clot formation (for PDS collection). Final supernatants were mixed with radioimmunoassay grade charcoal for $12 \mathrm{~h}$ at $4^{\circ} \mathrm{C}$ as previously described (13). Sera were dialyzed for $48 \mathrm{~h}$ against large volumes of $140 \mathrm{mM}$ sodium chloride, $10 \mathrm{mM}$ sodium phosphate, pH 7.4 (phosphate-buffered saline [PBS]). The dialyzed solutions were heated at $56^{\circ} \mathrm{C}$ for $30 \mathrm{~min}$, centrifuged at 31,000 $g$ for $30 \mathrm{~min}$ at $4^{\circ} \mathrm{C}$, and sterilized by passage through a $0.45-\mu \mathrm{m}$ Millipore filter (Millipore Corp., Bedford, MA). They were stored at either $4^{\circ} \mathrm{C}$ or $-20^{\circ} \mathrm{C}$ until use. Assays for insulin, IGF, and PDGF were performed on samples obtained before and after charcoal adsorption. IGF assays by radioimmunoassay were kindly performed by Dr. A. Moses (Beth Israel Hospital, Boston, MA) and PDGF measurements were made by Drs. E. W. Raines and R. Ross (both of University of Washington, Seattle, WA). Mean \pm SD values of four samples before and after charcoal adsorption for insulin were $24 \pm 10 \mu \mathrm{U} / \mathrm{ml}$, and undetectable activity, for IGF $296.9 \pm 71.6$ and $25.9 \pm 25.6 \mathrm{ng} / \mathrm{ml}$, and for PDGF $8.51 \pm 0.60$ and $0.15 \pm 0.02 \mathrm{ng} / \mathrm{ml}$ in WBS, and $<0.10 \mathrm{ng} / \mathrm{ml}$ in PDS, respectively. The PDS sample selected for insulin and IGF studies contained an undetectable level of IGF.

Samples of electrophoretically pure IGF-II prepared from germ-free medium conditioned by a clone of Buffalo rat liver cells (BRL-3A) (14) 
were kindly provided by Dr. M. P. Czech (University of Massachusetts, Worcester, MA). $20 \mu \mathrm{g}$ of lyophilized material were dissolved in 0.005 $\mathrm{N} \mathrm{HCl}$ and stored at $-20^{\circ} \mathrm{C}$ until it was used in culture. Highly purified crystalline porcine insulin $(27.0 \mathrm{U} / \mathrm{mg}$, proinsulin content of less than 20 parts per million [Eli Lilly \& Co., Indianapolis, IN]) was diluted in NCTC-109 (Microbiological Associates, Bethesda, MD) and stored at $4^{\circ} \mathrm{C}$ until use. Samples of electrophoretically pure PDGF were kind gifts of Dr. E. W. Raines and Dr. R. Ross. They were dissolved in $1 \mathrm{mM}$ acetic acid and diluted in PBS plus bovine serum albumin at a final protein concentration of $2 \mathrm{mg} / \mathrm{ml}$. Growth factor preparations were made to add to culture at a final volume of $100 \mu \mathrm{l}$. Concurrently tested controls for each marrow culture contained $100 \mu \mathrm{l}$ of NCTC-109.

Erythropoietic growth-promoting assays. Bone marrow cells were aspirated from the posterior iliac crests of 17 hemotologically normal volunteers into Eagle's minimum essential medium containing $20 \mathrm{U} / \mathrm{ml}$ preservative-free heparin (Gibco Laboratories, Grand Island, NY). Informed consent was obtained in accordance with Institutional Review Board policy. The nucleated cells were separated over Ficoll-Hypaque (Pharmacia Fine Chemicals, Piscataway, NJ), washed three times in Eagle's minimum essential medium and cultured at $6 \times 10^{5} / \mathrm{ml}$ in fibrin clots according to the method of Tepperman et al. (15), with the following modifications: the culture mixture was made with $27 \%$ (vol/vol) charcoaladsorbed PDS or WBS in the absence of thiol-containing compounds. Clot formation occurred in microtiter wells after addition of $0.1 \mathrm{mg} / \mathrm{ml}$ highly purified human fibrinogen (Kabi AG, Stockholm, Sweden), 2 $\mathrm{mM} \mathrm{CaCl}{ }_{2}$, and 1-2 $\mathrm{U} / \mathrm{ml}$ thrombin. Sheep Step III erythropoietin (Connaught Laboratories, Willowdale, Ontario, Canada) was added to achieve a final concentration of $2 \mathrm{IU} / \mathrm{ml}$. For dose-response experiments, highly purified human erythropoietin $(70,000 \mathrm{IU} / \mathrm{mg})$ obtained from Dr. Goldwasser (University of Chicago, IL) was used.

In some cases, growth factors were tested for erythropoietic activity in human marrow cultures containing no added serum (16). These cultures contained Iscove's modified Dulbecco's medium (IMDM) (Gibco Laboratories), $248 \mu \mathrm{g} / \mathrm{ml}$ highly purified human transferrin (Sigma Chemical Co., St. Louis, MO; $\sim 98 \%$ pure), $1.63 \mu \mathrm{g} / \mathrm{ml}$ ferric chloride $\left(\mathrm{FeCl}_{3} \cdot 6 \mathrm{H}_{2} \mathrm{O}\right)$, and $117 \mu \mathrm{g} / \mathrm{ml}$ electrophoretically pure human albumin (17).

Clots were removed from microtiter wells $(125 \mu \mathrm{l})$, fixed to glass slides in glutaraldehyde, and stained with benzidine and hematoxylin. CFU-E-derived colonies appearing after $7 \mathrm{~d}$ of incubation contained 8 to 49 benzidine-positive cells. Erythroid bursts appearing after $12 \mathrm{~d}$ contained more than 50 benzidine-positive cells or consisted of three or more aggregates of 10 to 49 benzidine-positive cells. Colonies and bursts were enumerated under 100 -fold magnification. For cultures containing serum, actual mean CFU-E- and BFU-E-derived colony growth ranged from 15 to 78 and from 10 to 34 colonies, respectively, in $125 \mu$ l clots containing $2.0 \mathrm{IU} / \mathrm{ml}$ erythropoietin. The respective seeding efficiencies were from 120 to 624 CFU-E-derived colonies and from 80 to 272 BFU-E-derived colonies per $6 \times 10^{5}$ marrow cells $/ \mathrm{ml}$. For serum-depleted cultures, actual mean growth ranged from 17 to 55 and from 13 to 26 colonies, respectively. This represents 136 to 440 colonies and 104 to 208 bursts per $6 \times 10^{5}$ marrow cells $/ \mathrm{ml}$, respectively. The ability of each growth factor to support colony formation alone or in combination was calculated as percent maximum colonies, with $100 \%$ growth occurring in cultures containing $27 \%$ serum plus $100 \mu 1$ NCTC-109 or NCTC-109 alone.

Preparation and assay of conditioned medium (CM). Approximately $100 \mathrm{ml}$ of peripheral blood was collected from a healthy volunteer into alpha-medium (320-2561; Gibco Laboratories) containing heparin. FicollHypaque separated mononuclear cells were incubated for $90 \mathrm{~min}$ at $37^{\circ} \mathrm{C}$ in $5 \% \mathrm{CO}_{2}$ in humidified air. Nonadherent cells were washed three times and resuspended in serum-free alpha-medium supplemented with L-glutamine, streptomycin, and penicillin at $5 \times 10^{6} / \mathrm{ml}$ in $25-\mathrm{cm}^{2}$ tissue culture flasks (Corning Glass Works, Corning, NY). Control medium was incubated in the absence of cells. After 24-h incubation, test medium was freed of cells by centrifugation at $280 \mathrm{~g}$ for $20 \mathrm{~min}$. Cell viability was $>\mathbf{9 8 \%}$ by trypan blue exclusion. BPA present in CM was assayed in serum depleted culture at final concentrations of $0.0,4.5,9.0,13.5$, and
$20 \%$ (vol/vol) in the presence and absence of IGF-II. Burst formation was compared with that present in cultures containing additional IMDM but no added CM or growth factor.

Statistical analysis. The mean \pm 1 SE actual number of colonies formed in quadruplicates of $125 \mu \mathrm{l}$ each was determined, and data sets were compared by the two sample ranks test of Wilcoxon-White (18).

\section{Results}

Colony stimulation by insulin and IGF-II. Fig. 1 shows that insulin and IGF-II stimulate both CFU-E- and BFU-E-derived colony formation in cultures with charcoal-adsorbed PDS $(P$ $<0.05$ ). Dose response curves for IGF-II are shifted leftward by one to two orders of magnitude relative to those for insulin. When tested in serum-depleted culture, colony stimulation was also observed (see Table I). Enhancement of colony formation in cultures with defined medium was greater at the final protein concentrations of 0.1 and $1.0 \mathrm{ng} / \mathrm{ml}$ than in serum-containing culture $(P<0.05)$. No colonies formed in the absence of added erythropoietin. The data indicate that both insulin and IGF-II potentiate erythroid progenitor cell proliferation.

Interactions of insulin and IGF-II with erythropoietin and erythroid BPA. We next tested whether insulin or IGF-II can supplant growth factors having apparent erythropoietic specificity. Fig. 2 shows the effects of $10 \mathrm{ng} / \mathrm{ml}$ of insulin and $1 \mathrm{ng} / \mathrm{ml}$ of IGF-II capable of expressing approximately half maximal stimulation in cultures containing various amounts of highly purified erythropoietin. Erythropoietic action on colony growth of insulin and IGF-II was expressed at each erythropoietin concentration tested $(P<0.05)$.

Since both IGF-II and BPA are derived from serum-free medium exposed for a short time to mammalian cells, we asked

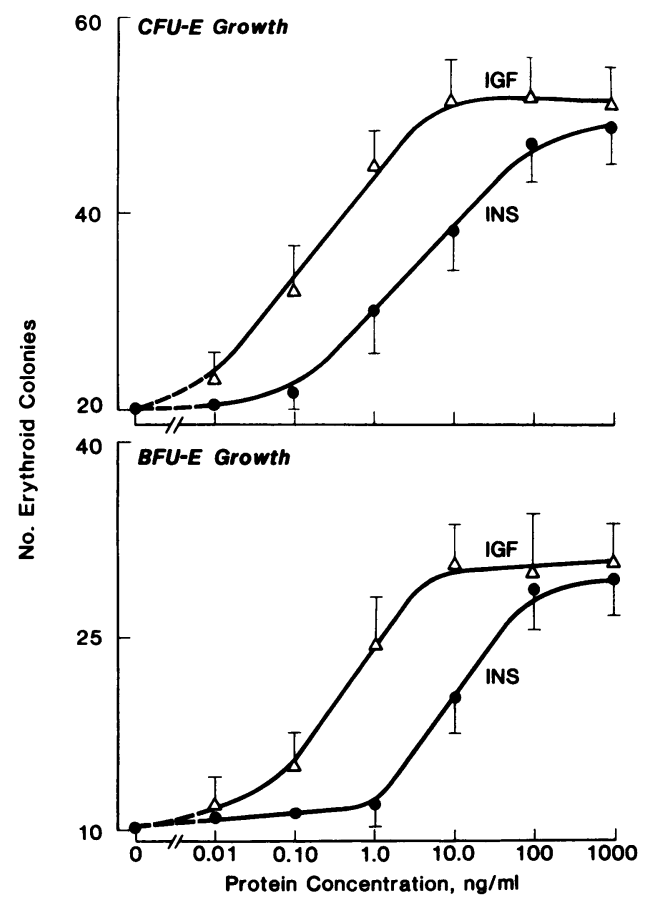

Figure 1. Stimulation of colony formation by insulin and IGF. The graph shows mean \pm SE colonies in quadruplicate $125-\mu 1$ cultures containing charcoal-adsorbed PDS. All cultures contained $2 \mathrm{IU} / \mathrm{ml}$ of erythropoietin and NCTC-109, insulin (circles), or IGF-II (triangles) at the indicated final protein concentrations. Similar results were obtained in two additional studies. 
Table I. Colony Stimulation by Insulin and IGF-II in Serum-depleted and Serum-containing Culture

\begin{tabular}{lccc}
\hline & \multicolumn{3}{c}{$\begin{array}{l}\text { No. of colonies } \\
\text { per } 6 \times 10^{5} \text { cells }\end{array}$} \\
\cline { 3 - 4 } Addition to culture & PDS & Day 7 & Day 12 \\
\hline IMDM alone & - & $0 \pm 0$ & $0 \pm 0$ \\
NCTC-109 alone & + & $0 \pm 0$ & $0 \pm 0$ \\
Erythropoietin + IMDM & - & $15 \pm 2$ & $10 \pm 1$ \\
Erythropoietin + NCTC-109 & + & $16 \pm 3$ & $11 \pm 2$ \\
Erythropoietin plus: & & & \\
$\quad$ Insulin $(0.1 \mathrm{ng} / \mathrm{ml})$ & + & $20 \pm 1$ & $14 \pm 2$ \\
& - & $15 \pm 2$ & $12 \pm 4$ \\
$\quad$ Insulin $(1.0 \mathrm{ng} / \mathrm{ml})$ & + & $25 \pm 3$ & $17 \pm 3$ \\
& - & $19 \pm 2$ & $12 \pm 3$ \\
Insulin $(10 \mathrm{ng} / \mathrm{ml})$ & + & $24 \pm \pm 4$ & $21 \pm 3$ \\
& - & $24 \pm 3$ & $18 \pm 2$ \\
IGF-II $(0.1 \mathrm{ng} / \mathrm{ml})$ & + & $19 \pm 2$ & $18 \pm 3$ \\
& - & $29 \pm 4$ & $26 \pm 4$ \\
IGF-II $(1.0 \mathrm{ng} / \mathrm{ml})$ & + & $23 \pm 3$ & $17 \pm 2$ \\
& - & $32 \pm 3$ & $26 \pm 2$ \\
IGF-II $(10 \mathrm{ng} / \mathrm{ml})$ & + & $25 \pm 2$ & $21 \pm 3$ \\
& & &
\end{tabular}

Mean \pm SE colonies are shown in $125-\mu l$ quadruplicate serum-free and serum-containing (27\% charcoal-adsorbed PDS) cultures. Albumin, transferrin, and ferric chloride were omitted from cultures containing PDS. The erythropoietin dose of $2 \mathrm{IU} / \mathrm{ml}$ was used where indicated. Similar results were observed in one additional study.

whether IGF-II mimics the activity of CM prepared by incubation with human peripheral blood mononuclear cells. As shown in Fig. 3, $10 \mathrm{ng} / \mathrm{ml}$ of IGF-II stimulated burst formation at suboptimal and optimal $(>9.0 \%) \mathrm{CM}$ concentrations. However, when added to cultures containing CM made in the absence of conditioning cells, IGF-II did not express BPA-like activity (see Fig. 3). This was true regardless of the amount of IGF-II added to culture.

Interactions of insulin, IGF-II, and PDGF in culture. To further characterize the erythropoietic actions of insulin and IGF-II, we determined the effects of serum concentration on hormone activity. Fig. 4 shows insulin and IGF-II activity as a function of PDS and WBS concentration. At 9 and 27\% serum concentrations, the number of day-7 colonies in PDS-containing cultures was significantly lower than that observed in WBS-containing cultures. Both insulin and IGF-II augmented colony growth at the same rate, regardless of PDS or WBS concentration (see Fig. 4). Since the presence of PDGF is likely responsible for superior colony formation with WBS, we next tested the influence of purified PDGF on insulin and IGF-II activity.

Fig. 5 shows our results in serum-free cultures containing PDGF plus various amounts of insulin or IGF-II. Day-7 colony formation was higher $(P<0.05)$ at each hormone concentration in cultures with $10^{-4} \mathrm{ng} / \mathrm{ml}$ of PDGF relative to those containing $10^{-5} \mathrm{ng} / \mathrm{ml}$. The dose-proliferation response curve for each hormone is shifted upward at the higher PDGF concentration. This finding suggests that PDGF activity is synergistic with activities of insulin and IGF-II.

We next tested whether insulin and IGF activities themselves are synergistic. Fig. 6 shows day-7 colony stimulation by

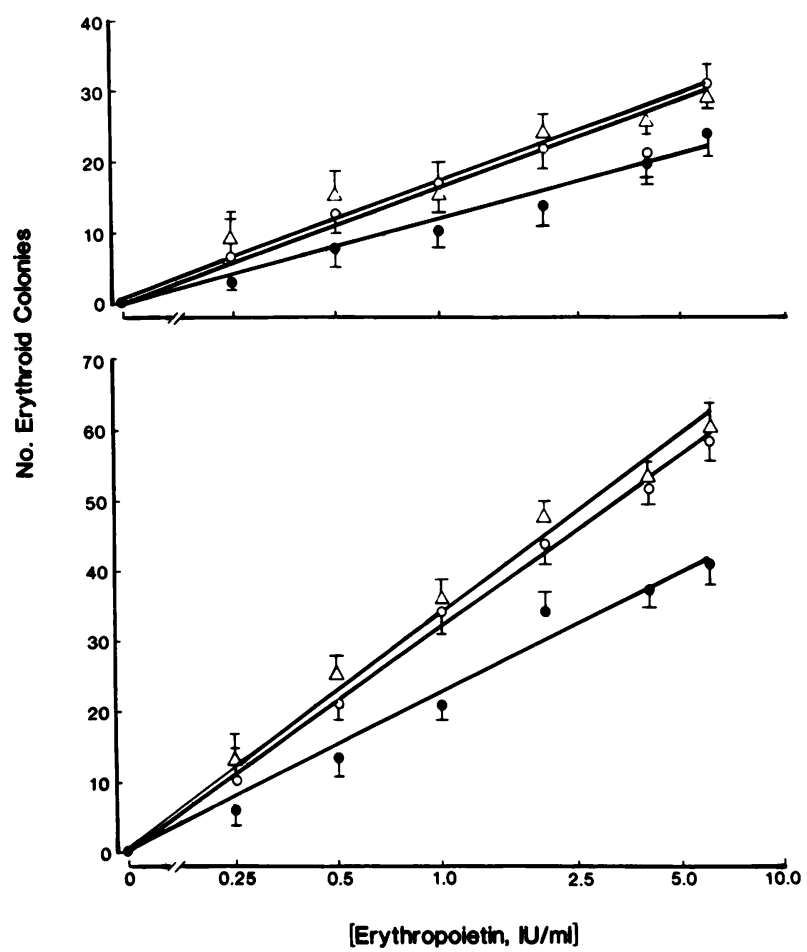

Figure 2. Insulin and IGF activity as function of erythropoietin concentration. Highly purified erythropoietin was added to serum-depleted cultures that were scored for CFU-E-derived (bottom) and BFU-E-derived (top) colony formation. Mean \pm SE colonies are shown in $125-\mu 1$ quadruplicates containing NCTC-109 (closed circles), $10 \mathrm{ng} /$ $\mathrm{ml}$ of insulin (open circles), or $1 \mathrm{ng} / \mathrm{ml}$ of IGF-II (triangles).

IGF-II or insulin containing from zero to $100 \mathrm{ng} / \mathrm{ml}$ of insulin or from zero to $1.0 \mathrm{ng} / \mathrm{ml}$ IGF-II. At a suboptimal IGF and insulin concentration, addition of the other growth factor resulted in stimulation that was additive. However, at an optimal concentration of either factor, stimulation by the other factor was reduced. Similar results were obtained with day- 12 colony formation (data not shown). Therefore, the erythropoietic effects of insulin and IGF-II are additive.

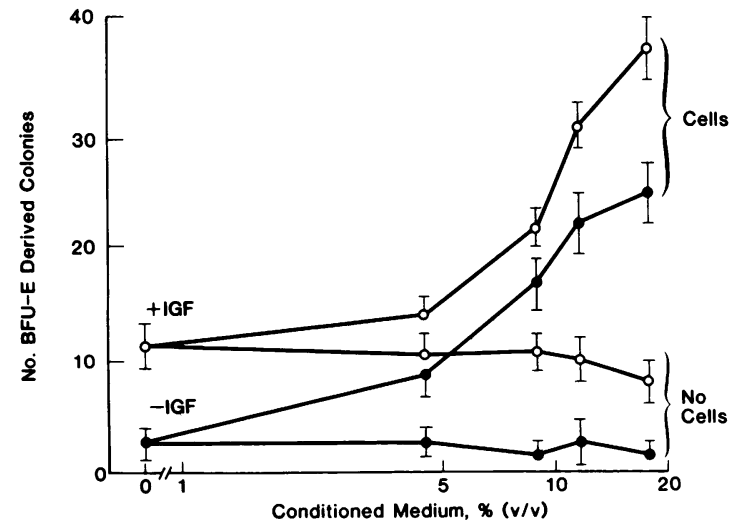

Figure 3. IGF effects as function of CM concentration. The graph shows mean $\pm \mathrm{SE}$ growth in $125-\mu$ l quadruplicate serum-depleted cultures containing $2 \mathrm{IU} / \mathrm{ml}$ of erythropoietin plus either $10 \mathrm{ng} / \mathrm{ml}$ of IGF-II (open circles) or NCTC-109 (closed circles). CM was prepared in the presence and absence of circulating mononuclear cells. 


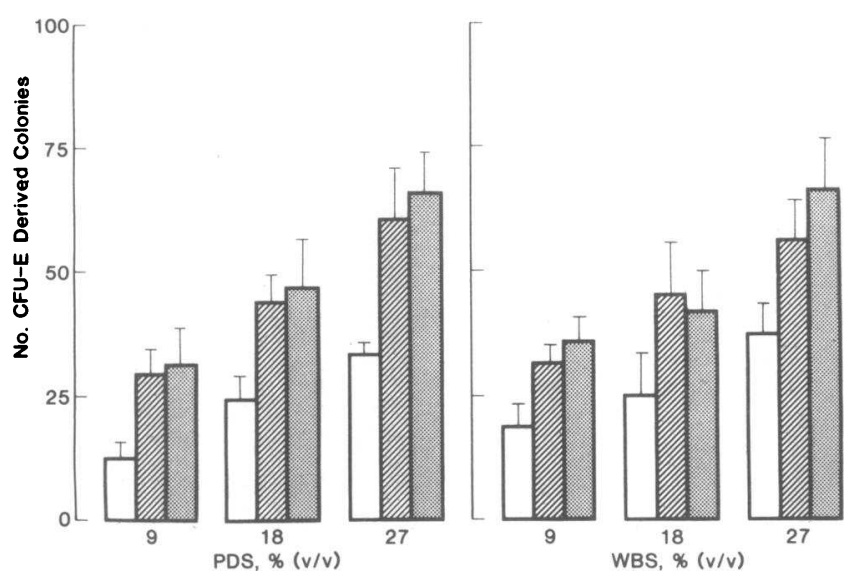

Figure 4. Insulin and IGF activities as function of serum concentration. Mean \pm SE CFU-E-derived colony formation is shown for $125-\mu \mathrm{l}$ quadruplicate cultures established with $9 \%, 18 \%$, or $27 \%$ (vol/vol) charcoal-adsorbed PDS (left) or WBS (right). Cultures contained 2 IU/ $\mathrm{ml}$ of erythropoietin plus NCTC-109 (open bars), $10 \mathrm{ng} / \mathrm{ml}$ of insulin (cross-hatched bars), or $1 \mathrm{ng} / \mathrm{ml}$ of IGF-II (stippled bars). Similar results were obtained for day-12 colonies (data not shown).

\section{Discussion}

A variety of hormones and paracrines has been demonstrated to augment erythroid colony formation in culture, including thyroid hormones, steroids, growth hormones, and prostaglandins (4-6, 19-21). In addition, insulin has been shown to potentiate human peripheral blood BFU-E proliferation and murine marrow and fetal liver-derived CFU-E proliferation in serum-supplemented culture $(20,22,23)$. In this communication, we show that insulin also stimulates erythroid progenitor cell growth by normal human bone marrow mononuclear cells. Furthermore, addition of IGF to hormone-exhausted and to serum-

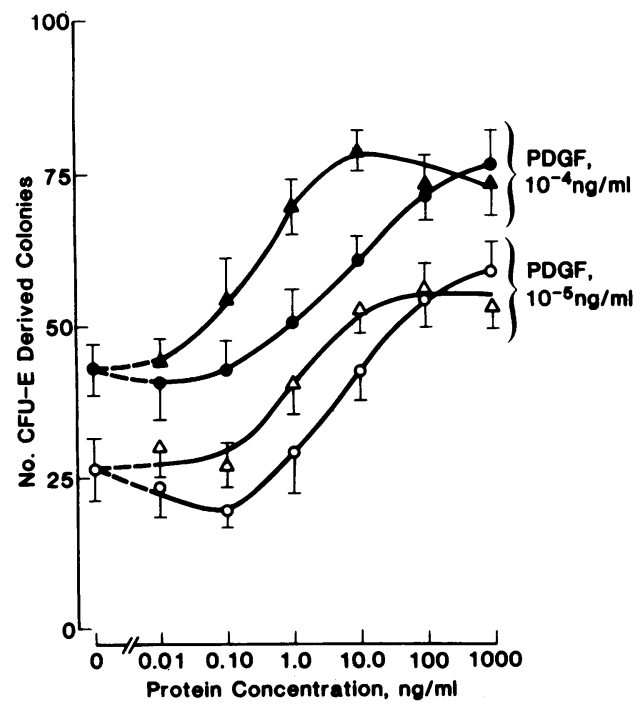

Figure 5. Effects of PDGF on insulin and IGF activity. The graph shows mean \pm SE colony growth in $125-\mu$ l clots containing $2 \mathrm{IU} / \mathrm{ml}$ of erythropoietin plus serum-free constituents. PDGF was added at the indicated final concentrations to cultures with $100 \mathrm{ng} / \mathrm{ml}$ of insulin (circles) or $10 \mathrm{ng} / \mathrm{ml}$ of IGF-II (triangles). Similar results were obtained in day-12 cultures (data not shown).

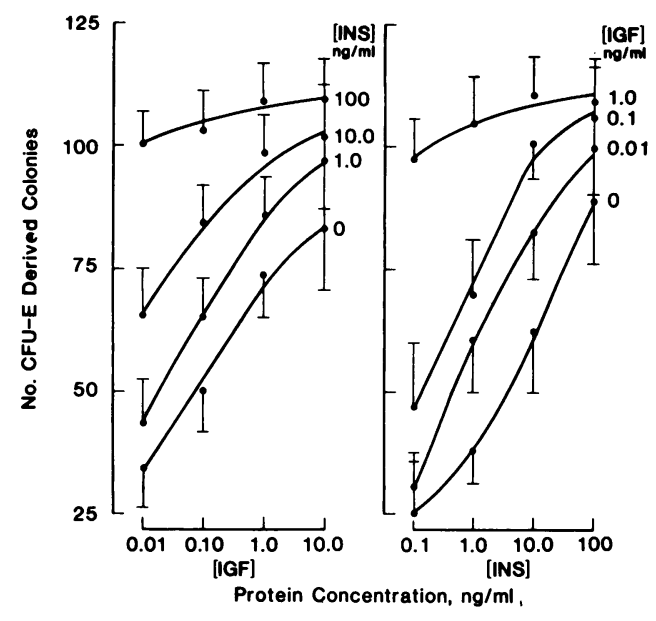

Figure 6. Effects of insulin and IGF added in combination to culture. Mean \pm SE colony growth is displayed for $125-\mu$ l fibrin clots formed with charcoal-adsorbed PDS. All cultures contained $2 \mathrm{IU} / \mathrm{ml}$ of erythropoietin plus either from 0.01 to $10 \mathrm{ng} / \mathrm{ml}$ of IGF-II (left) or from 0.1 to $100 \mathrm{ng} / \mathrm{ml}$ insulin (right). Results are shown for cultures containing from zero to $100 \mathrm{ng} / \mathrm{ml}$ insulin (left) or from zero to $1 \mathrm{ng} / \mathrm{ml}$ IGF-II (right).

depleted culture enhances colony formation in a saturable fashion. When insulin and IGF are added together at a suboptimal concentration, addition of the other growth factor results in an additive stimulatory effect. However, stimulatory activity is nonadditive when an optimal amount of either is used.

In addition to its action on metabolism of mammalian cells, insulin has been shown to be mitogenic for a wide spectrum of cells in culture (24-26). These activities appear to have evolved in a distinct fashion (27). In most cases, pharmacologic amounts $(>1 \mu \mathrm{g} / \mathrm{ml}$ or $25,000 \mu \mathrm{U} / \mathrm{ml}$ ) are required to elicit a proliferation response $(7-9,28)$. It is unclear why such high concentrations are required for a biological response. Since one possible explanation is that insulin is mitogenic by virtue of its capacity to bind weakly to cell receptors for IGF, we were prompted to examine the effects of this growth factor in erythropoietic culture. Our findings that the effects of insulin and IGF are additive (see Fig. 5) and that the dose-response curve for IGF is shifted leftward relative to that for insulin (see Fig. 1) are consistent with the hypothesis that alterations in an IGF receptor system may lead to enhanced erythroid progenitor proliferation. On the other hand, alterations in postreceptor events may also explain our results. Studies employing competitive binding of insulin and IGF to native and cross-linked receptors on human marrow subpopulations will be useful to approach this question (studies in progress).

High concentrations of serum $(>15 \%)$ are routinely used in erythropoietic culture. Since the hormone component must first be removed from serum to demonstrate consistently a hormonedependent effect on the growth of erythroid and other cell types $(6,29)$, we used either serum additives that contained an undetectable amount of insulin and IGF after adsorption to activated charcoal, or biochemically defined culture medium. Variable serum levels of insulin, IGF, and other polypeptides may possibly explain inconsistent findings relative to the optimal insulin dose required for an effect on cultured erythroid cells $(20$, $22,23)$. Moreover, since insulin effect on cell cycle may be related to the density of cells plated (30), the seeding density as well as 
cell species and tissue (i.e., peripheral blood, bone marrow, or fetal liver) cultured may also be important variables.

Several of our observations suggest that insulin and IGF are distinct from other erythropoietic growth factors. First, their activity is synergistic with but cannot replace that of erythropoietin in culture (see Fig. 2). Second, the erythropoietic effect of IGFII is similar when assayed in the presence and absence of BPA, regardless of the CM concentration tested (see Fig. 3). And third, insulin and IGF activities are similar when assayed with PDS and WBS. Furthermore, the effects of purified PDGF are synergistic with those of insulin and IGF, suggesting that the erythropoietic activity of PDGF is also distinct.

The critical hematopoietic target cell population(s) of insulin and IGF are unknown. It is possible that erythroid progenitors are directly affected or that accessory cells are targeted that are known to have receptors for those polypeptides, such as fibroblasts, mononuclear leukocytes, or endothelial cells (31-33). Cells of mesenchymal origin are known to exert regulatory effects on the rate of hematopoietic cell growth $(34,35)$. Therefore, it is possible that insulin and IGF exert an indirect action similar to that postulated for PDGF (36), in which important cellular interactions within the local culture environment are activated that in turn accelerate erythroid differentiation and/or proliferation.

Finally, the importance of our findings in erythropoiesis in vivo is undefined. However, recently a serum mitogen having erythropoietin-like activity has been partially sequenced and found to have a high degree of homology with IGF-II (37). It is possible that circulating members of the somatomedin family play an etiologic role in hypoproliferative anemias known to complicate endocrinologic diseases and disorders associated with abnormal insulin and/or IGF binding, such as diabetes mellitus, malnutrition, and selected malignancies (38-40). Studies aimed at evaluating erythropoietic responses in vitro from anemic and nonanemic patients with such disorders may be useful in exploring this hypothesis.

In conclusion, we have found that insulin and IGF-II enhance erythroid colony formation by human bone marrow cells. Their activities may be explained by activation of a common receptor or postreceptor system. While target cells remain undefined, it is possible that IGF-II and insulin enhance sensitivity to erythropoietic growth factors from which they are distinct, such as erythropoietin, BPA, and PDGF. Further studies are indicated to dissect their mechanisms of erythropoietic action and physiological relevance.

\section{Acknowledgments}

We are grateful to Dr. Michael P. Czech for his generous supply of purified IGF-II, to Dr. Russell Ross and Dr. Elaine W. Raines for their supply of purified PDGF, and to Dr. Eugene Goldwasser for kindly providing highly purified erythropoietin.

This work was supported in part by National Institutes of Health grants AM27071 and AM31060 to Dr. Dainiak.

\section{References}

1. Eagle, H. 1955. Nutrition needs of mammalian cells in tissue culture. Science (Wash. DC). 122:501-504.

2. Ham, R. G., and W. L. McKeehan. 1978. Development of improved media and culture conditions for clonal growth of normal diploid cells. In Vitro. 14:11-22.

3. Hayashi, I., and G. H. Sato. 1976. Replacement of serum by hor- mones permits growth of cells in a defined medium. Nature (Lond.). 259:132-134.

4. Golde, D. W., N. Bersch, and M. J. Cline. 1978. Hormonal effects on erythroid stem cells. In Cellular and Molecular Regulation of Hemoglobin Switching. G. Stamatoyannopoulos and A. W. Nienhuis, editors. Grune \& Stratton, New York. 305-321.

5. Adamson, J. W. 1981. Hormonal interactions in erythropoiesis. In Hemoglobins in Development and Differentiation. G. Stamatoyannopoulos and A. W. Nienhuis, editors. Alan R. Liss, New York. 73-84.

6. Dainiak, N. 1985. Role of defined and undefined serum additives to hematopoietic stem cell culture. In Hematopoietic Stem Cell Phsyiology. E. P. Cronkite, N. Dainiak, R. McCaffrey, J. Palek, and P. Quesenberry, editors. Alan R. Liss, New York. 59-76.

7. Vaheri, A., E. Ruoslahti, T. Hovi, and S. Nordling. 1973. Stimulation of density-inhibited cell cultures by insulin. J. Cell. Physiol. 81: 355-364.

8. Baseman, J. B., D. Paolini, Jr., and H. Amos. 1974. Stimulation by insulin of RNA synthesis in chick fibroblasts. J. Cell. Biol. 60:54-64.

9. Baseman, J. B., and N. S. Hayes. 1975. Differential effect of hormones on macromolecular synthesis and mitosis in chick embryo cells. J. Cell. Biol. 67:492-497.

10. Dainiak, N., G. Davies, M. Kalmanti, J. Lawler, and V. Kulkarni. 1983. Platelet-derived growth factor promotes proliferation of erythropoietic progenitor cells in vitro. J. Clin. Invest. 71:1206-1214.

11. Vogel, A., E. Raines, B. Kariya, M. Rivest, and R. Ross. 1978. Coordinate control of $3 \mathrm{~T} 3$ cell proliferation by platelet-derived growth factor and plasma components. Proc. Natl. Acad. Sci. USA. 75:28102814.

12. Vogel, A., R. Ross, and E. Raines. 1980. Role of serum components in density-dependent inhibition of growth of cells in culture. Platelet-derived growth factor is the major serum determinant of saturation density. J. Cell. Biol. 85:377-385.

13. Kalmanti, M., N. Dainiak, J. Martino, M. Dewey, V. Kalkami, and D. Howard. 1982. Correlation of clinical and in vitro erythropoietic responses to androgens in renal failure. Kidney Int. 22:383-391.

14. Marquardt, H., G. J. Todaro, L. E. Henderson, and S. Oroszlan. 1981. Purification and primary structure of a polypeptide with multiplication-stimulating activity from rat liver cell cultures. J. Biol. Chem. 256:6859-6865.

15. Tepperman, A. D., J. E. Curtis, and E. A. McCulloch. 1974. Erythropoietic colonies in cultures of human marrow. Blood. 44:659669.

16. Dainiak, N., S. Kreczko, A. Cohen, R. Pannell, and J. Lawler. 1985. Primary human marrow cultures for erythroid bursts in a serumsubstituted system. Exp. Hematol. (Lawrence). In press.

17. Travis, J., J. Bowen, D. Tewksbury, D. Johnson, and R. Pannell. 1976. Isolation of albumin from whole human plasma and fractionation of albumin-depleted plasma. Biochem. J. 157:301-306.

18. Goldstein, A. 1964. Biostatistics: An Introductory Text. The Macmillan Company, New York. 62-63.

19. Dainiak, N., R. Hoffman, L. A. Maffei, and B. G. Forget. 1978. Potentiation of human erythropoiesis in vitro by thyroid hormone. Nature (Lond.). 272:260-262.

20. Golde, D. W. 1979. In vitro effects of growth hormone. In Growth Hormone and Other Biologically Active Peptides. A. Pecile and E. E. Muller, editors. International Congress Series No. 495, Excerpta Medica, Amsterdam, 52-62.

21. Dainiak, N., R. Hoffman, A. K. Ritchey, V. Floyd, and M. Callahan. 1980. In vitro steroid sensitivity testing: a possible means to predict response to therapy in primary hypoproliferative anemias. $\mathrm{Am}$. J. $\mathrm{He}$ matol. 9:401-412.

22. Bersch, N., J. E. Groopman, and D. W. Golde. 1982. Natural and biosynthetic insulin stimulates the growth of human erythroid progenitors in vitro. J. Clin. Endocrinol. Metab. 55:1209-1211.

23. Kurtz, A., W. Jelkmann, and C. Bauer. 1983. Insulin stimulates erythroid colony formation independently of erythropoietin. Br. J. Haematol. 53:311-316.

24. Temin, H. M. 1967. Studies in carcinogenesis: avian sarcoma 
viruses. VI. Differential multiplication of uninfected and converted cells in response to insulin. J. Cell. Physiol. 69:377-384.

25. Hollenberg, M. D., and P. Cuatrecasas. 1975. Insulin and epidermal growth factor: human fibroblast receptors related to deoxyribonucleic acid synthesis and amino acid uptake. J. Biol. Chem. 250:38453853.

26. Barnes, D., and G. Sato. 1980. Methods for growth of cultured cells in serum-free medium. Anal. Biochem. 102:255-270.

27. King, G. L., and C. R. Kahn. 1981. Non-parallel evolution of metabolic and growth-promoting functions of insulin. Nature (Lond.). 292:644-646.

28. Hollenberg, M. D., and P. Cuatrecasas. 1973. Epidermal growth factor: receptors in human fibroblasts and modulation of action by cholera toxin. Proc. Natl. Acad. Sci. USA. 70:2964-2968.

29. Nishikawa, K., A. Armelin, and G. Sato. 1975. Control of ovarian cell growth in culture by serum and pituitary factors. Proc. Natl. Acad. Sci. USA. 72:783-787.

30. Teng, M.-H., J. C. Bartholomew, and M. J. Bissell. 1976. Insulin effect on the cell cycle: analysis of the kinetics of growth parameters in confluent chick cells. Proc. Natl. Acad. Sci. USA. 73:3173-3177.

31. Czech, M. P. 1977. Molecular basis of insulin action. 46:359384.

32. Nissley, S. P., M. M. Rechler, A. C. Moses, P. A. Short, and J. M. Podskalny. 1977. Proinsulin binds to a growth peptide receptor and stimulates DNA synthesis in chick embryo fibroblasts. Endocrinology. 101:708-716.
33. Bar, R. S. 1982. Interactions of insulin and insulin-like growth factors (IGF) with endothelial cells. Ann. N.Y. Acad. Sci. 401:150-162.

34. Ghio, R., G. Bianchi, B. Lowenberg, K. A. Dicke, and F. Ajmar. 1977. Effects of fibroblasts on the growth of erythroid progenitors in vitro. Exp. Hematol. (Lawrence). 5:341-347.

35. Quesenberry, P. J., and M. A. Grimbone. 1980. Vascular endothelium as a regulator of granulopoiesis: production of colony-stimulating activity by cultured human endothelial cells. Blood. 56:10601067.

36. Delwiche, F., E. Raines, J. S. Powell, R. Ross, and J. W. Adamson. 1983. Platelet derived growth factor (PDGF) enhances in vitro erythroid colony growth via stimulation of mesenchymal cells. Blood. 62:121a. (Abstr.)

37. Congote, L. F. 1985. Similarities in structure and function of bovine serum erythrotropin and human insulin-like growth factor II: two fetal erythroid cell stimulating factors. Biochem. Biophys. Res. Commun. 126:653-659.

38. Czech, M. P. 1981. Insulin action. Am. J. Med. 70:142-150.

39. Zapf, J., and E. R. Froesch. 1981. Radioimmunological determination of insulinlike growth factors I and II in normal subjects and in patients with growth disorders and extra-pancreatic tumor hypoglycemia. J. Clin. Invest. 68:1321-1330.

40. Unterman, T. G., R. M. Vazquez, A. J. Slas, P. A. Martyn, and L. S. Phillips. 1985. Nutrition and somatomedin. XIII. Usefulness of somatomedin-C in nutritional assessment. Am. J. Med. 78:228-234. 